\title{
A bibliometric analysis of the 100 most influential papers on COPD
}

\author{
This article was published in the following Dove Press journal: \\ International Journal of COPD \\ 25 March 2015 \\ Number of times this article has been viewed
}

\section{Wenchao $\mathrm{Gu}^{\prime}$ \\ Yaping Yuan' \\ Hua Yang' \\ Guangsheng $\mathrm{Qi}^{\mathrm{I}}$ \\ Xiaoyan Jin ${ }^{2}$ \\ Jin $\mathrm{Yan}^{2}$}

'Department of Respiratory Medicine, People's Hospital of Shanghai, Pudong New Area, ${ }^{2}$ Department of Respiratory Medicine, Tongren Hospital, Shanghai, People's Republic of China
Correspondence: Xiaoyan Jin

Department of Respiratory Medicine, Tongren Hospital, No 738, Yuyuan Road, Shanghai, 200050, People's Republic of China

Email dotjin@126.com
Objective: We aimed to identify the 100 top-cited articles published on chronic obstructive pulmonary disease (COPD) and to analyze their characteristics so as to provide information on the achievement and development in COPD research over the past decades.

Methods and materials: A comprehensive list of citation classics in COPD was generated by searching the Science Citation Index expanded database, using the keywords "COPD" or "chronic obstructive pulmonary disease" or "chronic obstructive pulmonary diseases". The 100 top-cited research papers were retrieved by reading the abstract or full text if needed. All eligible articles were read for basic information, including country of origin, organizations, article type, journals, research field, and authors.

Results: The 100 top-cited articles on COPD were published between 1966 and 2010. The number of citations ranged from 254 to 2,164 , with a mean of 450 citations for each article. These citation classics were from 32 countries, with 38 from the United States. The Imperial College London led the list of classics, with 16 papers. The 100 top-cited articles were distributed in 18 journals, with the American Journal of Respiratory, Critical Care Medicine, and Journal of the American Medical Association topping the list. Among the various fields, both respiratory system $(63 \%)$ and general internal medicine $(63 \%)$ were the most common fields of study for the 100 articles.

Conclusion: Our bibliometric analysis provides a historical perspective on the progress of scientific research on COPD. Articles originating from the United States and published in high-impact specialized respiratory journals are most likely to be cited in the field of COPD research.

Keywords: citation analysis, top-cited, chronic obstructive pulmonary disease

\section{Introduction}

Chronic obstructive pulmonary disease (COPD) continues to be an important cause of morbidity, mortality, and health care costs worldwide. As the global population ages, the burden of COPD will increase in the years to come. ${ }^{1-3}$ Numerous specialists and researchers have focused their efforts on COPD in an attempt to gain a better understanding of how comorbid diseases, different phenotypes, and risk factor affect the outcome of COPD patients. A great numbers of articles have been published annually and have given new insights into the mechanism or treatment of COPD. ${ }^{4-6}$ However, there still exists a lack of knowledge regarding the quality of scientific yield in relation to this area.

It is generally believed that publications represent the central part of a research process. In medicine, the number of times a paper is cited by other authors has been established as a widely used and logical measure of how much academic influence it has had in its subject area. The reporting of this type of citation analysis is widespread 
in the medical literature. ${ }^{7-16}$ One way to measure the academic importance of an article is the rate at which the work is quoted or referenced by other authors. ${ }^{7,11,16}$ The article referenced by another peer-reviewed article receives a "citation." The total number of citations that an article receives is not necessarily a measure of its academic quality or even its influence upon the practice of the author's or authors' peers. ${ }^{17}$ Nevertheless, it does testify to the readership of the particular article and the influence of the article in generating changes in practice, controversy, discussion, or further research. Citation is viewed as a direct measure of the recognition an article has received in its field. Citation analysis in specific journals and specific subject areas has become a popular method to assess the citation impact of a journal, article, or author. ${ }^{8,10-13,18-23}$

The Institute for Scientific Information (ISI) has been collecting citation and other academic impact information since 1945 and has been available electronically since 1979 . ISI (now a subsidiary of Thomson Corp) calls their newest journal citation system "Science Citation Index ${ }^{\circledR}$ (SCI) Expanded," and it is one of the databases available under the banner of Web of Science. Citation data from peer-reviewed articles are indexed from more than 10,000 high-impact journals, not only from the sciences and social sciences but also, from the arts and humanities.

This search used the electronic version of this database to determine which published articles in medical journals have been cited most often by other authors, by ranking the 100 top-cited works. By analyzing characteristics of these articles, we intended to determine what qualities make a COPD article important to the specialty.

\section{Materials and methods}

On June 30, 2014, authors searched Web of Science and identified the 100 top-cited articles relating to COPD (Table 1) published in professional journals from 1945 to date. The articles entitled using the terms "COPD" or "chronic obstructive pulmonary disease" or "chronic obstructive pulmonary diseases" were included in the research.

Each article in the most cited 100 was reviewed, and the basic information collected included authors, year of publications, source journal of the article, geographic origin of the authors, and study field (general internal medicine, respiratory system, cardiovascular system cardiology, immunology, microbiology, physiology, research experimental medicine, sports science, or surgery). The full texts were mainly selected by PubMed or ScienceDirect. In addition, other methods were also used to search for articles that were not found in the aforementioned database, for example, interlibrary lending and requests for help on the PubMed.cn website (http://paper.pubmed.cn/). This website is a Chinese language-based platform used by scholars to request and share literatures. Several articles were cited more often than others because of the difference in time since publication. Thus, a citation index was also determined for each article to control this error. The citation index was defined as the mean number of citation times per year.

Statistical analysis was performed using SPSS 17 (SPSS Inc., Chicago, IL, USA). Spearman correlation analysis was used to test the total citation times and number of citation times per year, with an alpha level of 0.05. Descriptive statistics were quantified as counts or percentages of parameters.

As this was a bibliometric analysis, it was not necessary to obtain Internal Review Board approval.

\section{Results}

A total of 22,210 papers were identified in the initial search for the period from 1960 to present, with 12,098 published as "article" and 1,436 classified as "review". Among them, 623 articles were cited more than 100 times. One hundred selected articles were published from 1966 to 2010, of which about $55 \%$ were published after 2000 . The mean number of citations was 450 (range 254 to 2,164), and seven papers were cited more than 1,000 times (Table 1). Annual average number of citations were correlated by total number of citations $\left(r_{\mathrm{s}}=0.659, P<0.0001\right)$.

The most cited paper, published by Rabe et $\mathrm{al}^{24}$ in 2007 , was an executive summary describing the global strategy for the diagnosis, management, and prevention of COPD. Interestingly, the second most cited paper, by Celli et $\mathrm{al}^{25}$ received 1,659 citations and was also a summary of standards for the diagnosis and treatment of patients with COPD, published in 2004. The third article, by Hogg et $\mathrm{al}^{26}$ was a randomized controlled trial (RCT) - the paper proved that 1) progression of COPD is associated with the accumulation of inflammatory mucous exudates in the lumen and infiltration of the wall by innate and adaptive inflammatory immune cells that form lymphoid follicles, and 2) these changes are coupled to a repair or remodeling process that thickens the walls of these airways. The most recent paper came from 2010 and was cited 367 times. This paper ${ }^{27}$ proposed use of the "frequent exacerbation phenotype" to predict COPD exacerbations, implicating an important target of exacerbation-prevention strategies across the spectrum of disease severity. The last paper on the most cited list was a cohort study, authored by Marquis et al from 2002 and cited 254 times to date, which 


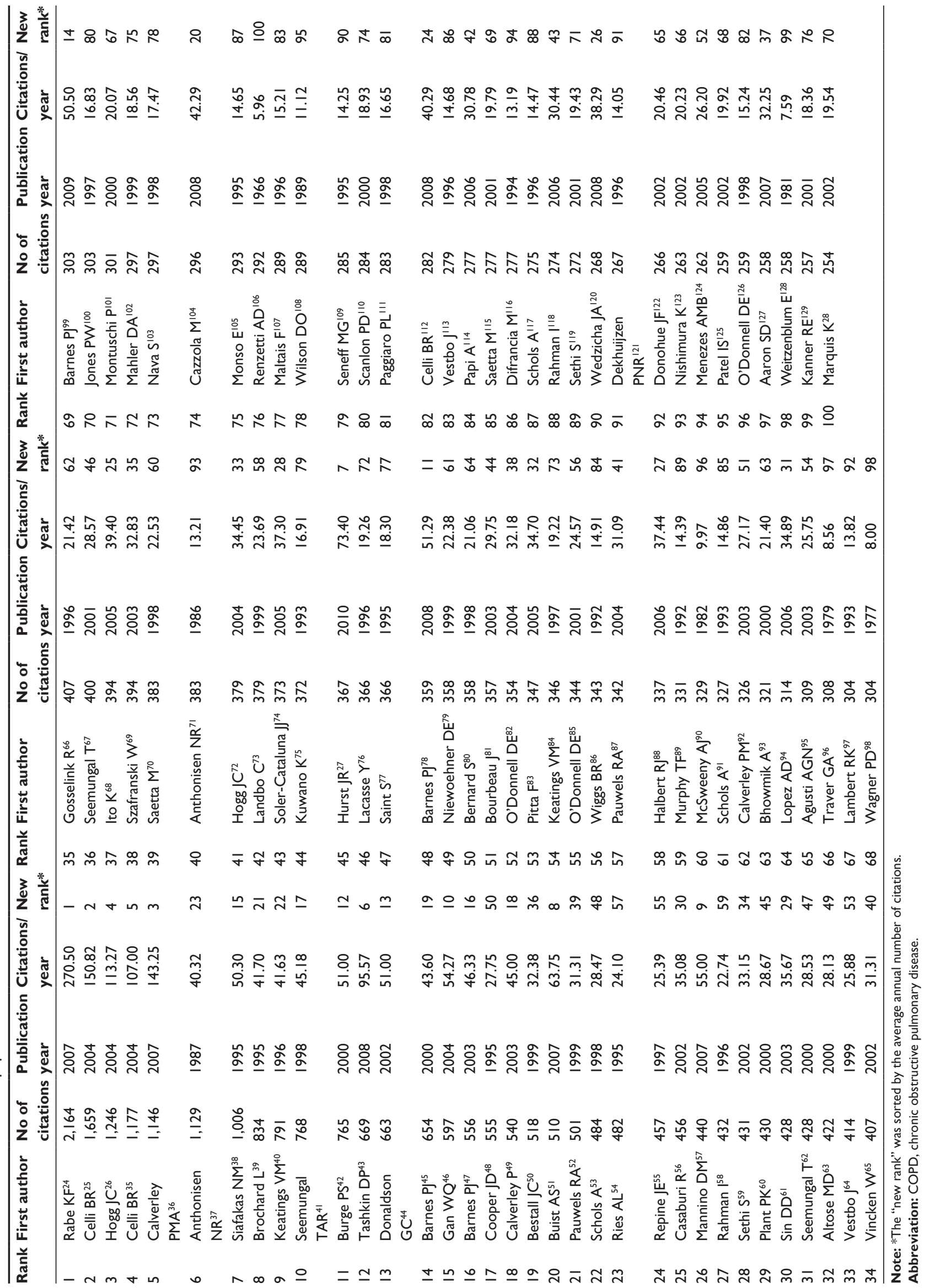


Table 2 Top-ten sources that contribute most articles to the top- 100 papers

\begin{tabular}{ll}
\hline Journal & Number \\
\hline American Journal of Respiratory and Critical Care & 30 \\
Medicine (Am J Respir Crit Care Med) & \\
European Respiratory Journal (Eur Respir J) & 14 \\
New England Journal of Medicine (N Engl J Med) & 12 \\
Lancet & 10 \\
Thorax & 8 \\
American Review of Respiratory Disease & 7 \\
(Am Rev Respir Dis) & \\
Annals of Internal Medicine (Ann Intern Med) & 4 \\
Chest & 3 \\
Archives of Internal Medicine (Arch Intern Med) & 2 \\
Journal of the American Medical Association & 2 \\
( Am Med Assoc) & \\
\hline
\end{tabular}

found that the midthigh muscle cross-sectional area was a better predictor of mortality than body mass index (BMI) in COPD patients; these findings suggest that the assessment of body composition may be useful in clinical practice. ${ }^{28}$

The 100 top-cited articles were published in 18 journals, predominantly in American Journal of Respiratory and Critical Care Medicine ( $\mathrm{n}=30$ ), followed by European Respiratory Journal $(\mathrm{n}=14)$ and New England Journal of Medicine $(\mathrm{n}=12)$ (Table 2).

The greatest number of top-cited articles were published in 1996, 2000, and 2002 ( $\mathrm{n}=8$ each). The least number of articles was published in the 1960s ( $\mathrm{n}=1$ [decade]). Articles on the list were divided into three periods, 1960 to 1989 (n=8), 1990 to $1999(\mathrm{n}=37)$, and after $2000(\mathrm{n}=55)$ (Table 3).

The country origins of the articles included: the United States ( $n=38)$, England $(n=34)$, Canada $(n=20)$, Netherlands $(\mathrm{n}=12)$, Italy $(\mathrm{n}=10)$, Belgium $(\mathrm{n}=9)$, Spain $(\mathrm{n}=8)$, Denmark $(n=7)$, Australia $(n=6)$, and Scotland $(n=5)$. The rest of the countries had less than five publications. Table 4 shows the distribution of top-cited articles over the countries of origin. Given some articles were authored with multiple sources of origin, especially those in the form of international research collaborations, the total number of countries of origin exceeded 100. The leading institutions are shown in Table 5. Imperial College London was found to be the most productive institution $(\mathrm{n}=16)$, followed by the University of London $(\mathrm{n}=10)$ and GlaxoSmithKline $(\mathrm{n}=9)$.
Among the 100 top-cited articles in COPD, the overwhelming majority ( $\mathrm{n}=63$ each) were studies belonging to "general internal medicine" and "respiratory system", followed by two studies in "cardiovascular system cardiology". Other fields, like "immunology", "microbiology" and "physiology" only had one article each (Table 6).

The top-cited papers were written by 749 authors and ranged from 1 to 70 per article. Three articles had one author, followed by eight articles with two authors, and eight articles with three authors. Table 7 presents a list of the most productive authors, showing that Barnes and Wedzicha each authored ten articles, followed by Vestbo $(n=8)$, Jones $(n=7)$, Buist ( $n=6)$, Calverley ( $n=6), \operatorname{Hogg}(n=6)$, Anthonisen ( $n=5)$, Celli ( $n=5)$, Maltais $(n=5)$, and Seemungal $(n=5)$ (Table 7).

\section{Discussion}

In medical literature, the number of times other authors reference an article is one measure of the influence of the publication, and this type of citation analysis strategy is widely used as a bibliometric study. The evaluation of specialty-wide citation analyses has been reported in other areas of medicine. ${ }^{7-9,18-21,23}$ However, the establishment of a citation rank list across a specialty, comprising many journals specific to an area of medicine, is a more complex process than citation analysis for one journal, although such analyses have been reported in some other areas of medicine. ${ }^{31-34}$

In this review, researchers ranked the top 100 articles by number of citations, in the specialty of COPD. The top article had 2,164 citations. Seven papers were cited more than 1,000 times, of which three were summaries of the most well-known international COPD management guidelines, by different research institutions or in different periods. However, they all represented the latest achievements of COPD development in their period and have played profound influence in COPD treatment and research development around the world. While the third-place paper was classic RCT research, the findings created a new therapy targets for COPD treatment. The fourth paper also was classic; the authors proved a multidimensional grading system (the BODE [BMI, airflow obstruction, dyspnea, and exercise] index) assessing the respiratory and systemic expressions of COPD would better categorize and predict outcome in COPD patients than the forced expiratory

Table 3 Decades distribution of the top- 100 most cited papers

\begin{tabular}{lllll}
\hline Year & Number & Mean number of citations & Minimum number of citations & Maximum number of citations \\
\hline$-1980 \mathrm{~s}$ & 8 & 412 & 258 & 1,129 \\
$1990 \mathrm{~s}$ & 37 & 413 & 259 & 1,006 \\
$2000 \mathrm{~s}$ & 55 & $48 \mathrm{I}$ & 254 & 2,164 \\
\hline
\end{tabular}


Table 4 Countries that contributed more than four papers in the 100 most influential papers

\begin{tabular}{ll}
\hline Country & Number \\
\hline USA & 38 \\
England & 34 \\
Canada & 20 \\
Netherlands & 12 \\
Italy & 10 \\
Belgium & 9 \\
Spain & 8 \\
Denmark & 7 \\
Australia & 6 \\
Scotland & 5
\end{tabular}

volume in one second $\left(\mathrm{FEV}_{1}\right)$. The fifth and sixth papers were specialized in the exploration of COPD drug therapy, and both of their groundbreaking discoveries have provided new directions for COPD treatment. In sum, the main reason for being so widely referenced is that the findings or conclusions reported in these papers have produced historical influence in COPD treatment and research history. However, every article on the list can be considered a citation "classic" by the frequently used, but somewhat arbitrary, marker of 100 pieces as the benchmark. ${ }^{29}$

This review of the most cited articles in COPD may be worthwhile for several reasons. First, the observations suggest the authors of citation classics in COPD have produced more highly cited articles than many of their colleagues in other specialties. Second, this study has successfully identified several attributes of articles in citation, indicating that journal and country of origin are very important factors. Finally, this paper might be considered as the first report on the most cited papers in COPD.

The study characteristics revealed here echo those found in similar reviews. The majority of articles originated in the United States. This result is in line with previous studies and is in accordance with the reported strong influence of

Table 5 The top-ten institutions contributing to the most cited articles in COPD

\begin{tabular}{ll}
\hline Institute & Number \\
\hline Imperial College London & 16 \\
University of London & 10 \\
GlaxoSmithKline & 9 \\
St Georges University London & 8 \\
University of British Columbia & 8 \\
University of California System & 8 \\
Oregon Health Science University & 7 \\
Oregon University System & 7 \\
Queen Mary University London & 7 \\
University of Copenhagen & 7
\end{tabular}

Abbreviation: COPD, chronic obstructive pulmonary disease.
Table 6 Research field of the most cited articles in COPD

\begin{tabular}{ll}
\hline Field & Number \\
\hline General internal medicine & 63 \\
Respiratory system & 63 \\
Cardiovascular system cardiology & 2 \\
Immunology & $\mathrm{I}$ \\
Microbiology & $\mathrm{I}$ \\
Physiology & $\mathrm{I}$ \\
Research experimental medicine & $\mathrm{I}$ \\
Sport sciences & $\mathrm{I}$ \\
Surgery & $\mathrm{I}$ \\
\hline
\end{tabular}

Abbreviation: COPD, chronic obstructive pulmonary disease.

the United States in research related to health science, ${ }^{8,12,14}$ indicating that American authors may be at an advantage. On the contrary, in Asian countries, although the scientific research has achieved rapid development in recent years, authors did not have a place in the COPD research field since their contribution in research productivity was rather disappointing. European countries, like England, Netherlands, Italy, etc, also showed a higher productivity. This finding seems to conform to the phenomenon "the better the economic ranking of a country, the higher the quantity and quality of its biomedical publications". ${ }^{30}$

Financial support from public foundations or commercial companies has evolved over time in response to changes in professional codes, laws, and markets. Public funds have given a great push to the development of medical research and public health. Industry-funded science has been widely debated because of the susceptibility to various kinds of biases. Nevertheless, it has played and will continue to play a critical role in the research process. Although this research did not analyze financial support separately, our findings showed that there was a commercial company ranked among the top-ten prolific institutions, which contributed a total of nine articles.

Although researchers were expecting a higher number, only $18 \%$ of the papers were review articles, whereas the majority were original research articles, which might be attributable to a preference for referencing experimental evidence rather than review articles or expert opinion.

It has been reported that scientific articles begin to be cited 1 or 2 years after publication and reach a maximum citation rate 7 to 10 years later after publication. ${ }^{26-28}$ It has also been reported that the "older" articles are, the greater the likelihood that they have attained more citations, purely because their citable period was longer. However, in our study, the citation rate gradually rose over the last decade and is indicative of an increasing consideration for the field of COPD.

Authors have to acknowledge that our study has several possible methodological limitations. First and foremost, this 
Table 7 The authors who contribute more than four articles to the top- 100 papers

\begin{tabular}{|c|c|c|}
\hline Author & Number of citation classics & Position on author list \\
\hline Barnes PJ ${ }^{24,40,45,47,68,78,84,99,101,104}$ & 10 & First author -4 , fourth -3 , sixth -1 , seventh -1 , others -1 \\
\hline Wedzicha JA $27,41,44,50,62,67,93,104,120,125$ & 10 & First author -1 , fourth -2 , fifth -1 , sixth -3 , others -3 \\
\hline Vestbo $J^{25,27,36,49,64,73,112,113}$ & 8 & First author -2 , second $-\mathrm{I}$, third $-\mathrm{I}$, fourth $-\mathrm{I}$, sixth $-\mathrm{I}$, eighth $-\mathrm{I}$, others $-\mathrm{I}$ \\
\hline Jones $\mathrm{PW}^{36,42,49,50,56,100,104}$ & 7 & First author -1 , third -2 , fifth -1 , sixth -2 , others -1 \\
\hline Buist $\mathrm{AS}^{24,25,51,57,88,110}$ & 6 & First author -1 , second -1 , fifth -1 , sixth -2 , others -1 \\
\hline Calverley PMA $24,36,42,49,92,120$ & 6 & First author -1 , second -2 , seventh $-I$, ninth $-I$, tenth -1 \\
\hline Hogg JC $26,68,72,75,86,97$ & 6 & First author -2, fourth $-I$, fifth $-I$, sixth $-I$, tenth $-I$ \\
\hline Anthonisen $\mathrm{NR}^{37,63,71,108,129}$ & 5 & First author -2 , second -1, fourth -1 , others - I \\
\hline Celli BR $25,35,36,99,112$ & 5 & First author -3 , second -1 , tenth -1 \\
\hline Maltais $\mathrm{F}^{28,80,81,107,127}$ & 5 & First author -1 , third -1 , fourth -1 , seventh -2 \\
\hline Seemungal TAR ${ }^{41,44,93,120,125}$ & 5 & First author -2 , second -3 \\
\hline
\end{tabular}

survey was restricted with the word "COPD" or "chronic obstructive pulmonary disease" or "chronic obstructive pulmonary diseases" in their titles. In other words, some significant COPD articles published under other titles might not have been included, and it is possible that these were good-quality articles with a high number of citations. Second, the journals have different approaches to accept or reject a submitted manuscript. Thus, particular journals could have stricter selection criteria that might have affected the clinical applicability or quality of their publications. The criteria could be a reason why most top-cited papers were found in one journal. Also, there are some intrinsic problems in using this method alone to evaluate the academic importance of one article, an author's or authors' publications, or the performance of a journal overall. First, this type of citation analysis does not account for self-citation, citations in textbooks and lectures, and an author's or authors' potential preference to cite articles in the journal in which they seek to publish their work. ${ }^{29}$ Second, language of publication plays a major role, with an obvious bias for articles published in English language journals. Third, there are biases inherent in the age of the database as any articles published in the 19th or early 20th century would be excluded, which likely causes some true "classic" articles to be excluded. Finally, previous study ${ }^{16}$ would tell us that in a scientific community, there is a tendency for adherence to a paradigm. In this context, this would mean that there is "snowball effect" to citations and that other authors are more likely to cite it because of previous citations, rather than for its content or quality. Despite these obvious defects, the data presented here do provide insight into the achievement and development of COPD research over the past decades.

\section{Acknowledgment}

This study was funded by Outstanding Leaders Training Program of Pudong Health Bureau of Shanghai (Grant
No PWR12014-04) and Key Discipline Construction Project of Pudong Health Bureau of Shanghai (Grant No PWZx2014-12).

\section{Author contributions}

Xiaoyan Jin and Wenchao Gu participated in the study design. Wenchao Gu, Yaping Yuan, Hua Yang, Guangsheng Qi, Xiaoyan Jin, and Jin Yan performed the data extraction and analysis. Hua Yang, Yaping Yuan, Guangsheng Qi and Jin Yan drafted the article. Xiaoyan Jin and Wenchao Gu wrote the manuscript.

\section{Disclosure}

The authors report no conflicts of interest in this work.

\section{References}

1. Simoens S. Cost-effectiveness of pharmacotherapy for COPD in ambulatory care: a review. J Eval Clin Pract. 2013;19(6):1004-1011.

2. Vestbo J, Hurd SS, Agustí AG, et al. Global strategy for the diagnosis, management, and prevention of chronic obstructive pulmonary disease: GOLD executive summary. Am J Respir Crit Care Med. 2013;187(4):347-365.

3. Han MK, Agusti A, Calverley PM, et al. Chronic obstructive pulmonary disease phenotypes: the future of COPD. Am J Respir Crit Care Med. 2010;182(5):598-604.

4. Repapi E, Sayers I, Wain LV, et al; Wellcome Trust Case Control Consortium; NSHD Respiratory Study Team. Genome-wide association study identifies five loci associated with lung function. Nat Genet. 2010;42(1):36-44.

5. Albert RK, Connett J, Bailey WC, et al; COPD Clinical Research Network. Azithromycin for prevention of exacerbations of COPD. $N$ Engl J Med. 2011;365(8):689-698.

6. Agusti A, Calverley PM, Celli B, et al; Evaluation of COPD Longitudinally to Identify Predictive Surrogate Endpoints (ECLIPSE) Investigators. Characterisation of COPD heterogeneity in the ECLIPSE cohort. Respir Res. 2010;11:122.

7. Zhang WJ, Ding W, Jiang H, Zhang YF, Zhang JL. National representation in the plastic and reconstructive surgery literature: a bibliometric analysis of highly cited journals. Ann Plast Surg. 2013;70(2):231-234.

8. Ye S, Xing R, Liu J, Xing F. Bibliometric analysis of Nobelists' awards and landmark papers in physiology or medicine during 1983-2012. Ann Med. 2013;45(8):532-538. 
9. Wiysonge CS, Uthman OA, Ndumbe PM, Hussey GD. A bibliometric analysis of childhood immunization research productivity in Africa since the onset of the Expanded Program on Immunization in 1974 BMC Med. 2013;11:66.

10. Whipple EC, Dixon BE, McGowan JJ. Linking health information technology to patient safety and quality outcomes: a bibliometric analysis and review. Inform Health Soc Care. 2013;38(1):1-14.

11. Ugolini D, Neri M, Cesario A, et al. Scientific production in cancer rehabilitation grows higher: a bibliometric analysis. Support Care Cancer. 2012;20(8):1629-1638.

12. Ugolini D, Neri M, Casilli C, et al. A bibliometric analysis of scientific production in mesothelioma research. Lung Cancer. 2010;70(2): 129-135.

13. Sun GH. Bibliometric analysis of health services research in otolaryngology journals. Otolaryngol Head Neck Surg. 2012;147(5) 841-847.

14. Ren Y, Wang QJ, Tian L, Wang C, Cui S, Zhang J. Bibliometric analysis on lung cancer in China during the period of 2001-2010. Thoracic Cancer. 2012;3(4):363-366

15. Nykiforuk CI, Osler GE, Viehbeck S. The evolution of smoke-free spaces policy literature: a bibliometric analysis. Health Policy. 2010; 97(1):1-7.

16. Mony PK, Srinivasan K. A bibliometric analysis of published noncommunicable disease research in India. Indian J Med Res. 2011;134: 232-234.

17. Cheek J, Garnham B, Quan J. What's in a number? Issues in providing evidence of impact and quality of research(ers). Qual Health Res. 2006; 16(3):423-435.

18. Joyce CW, Kelly JC, Sugrue C. A bibliometric analysis of the 100 most influential papers in burns. Burns. 2014;40(1):30-37.

19. Heinemann MK. Editor's commentary. Thorac Cardiovasc Surg. 2011;59(2):114.

20. Glanville J, Kendrick T, McNally R, Campbell J, Hobbs FD. Research output on primary care in Australia, Canada, Germany, the Netherlands, the United Kingdom, and the United States: bibliometric analysis. BMJ. 2011;342:d1028.

21. D'Arcangelo D, Giampietri C, Facchiano F, Facchiano A. BAMM: a preliminary bibliometric analysis on melanoma manuscripts. Pigment Cell Melanoma Res. 2013;26(3):415-417.

22. Cummings G, Biondo PD, Campbell D, et al. Can the global uptake of palliative care innovations be improved? Insights from a bibliometric analysis of the Edmonton Symptom Assessment System. Palliat Med. 2011;25(1):71-82.

23. Cohen JE, Chaiton MO, Planinac LC. Taking stock a bibliometric analysis of the focus of tobacco research from the 1980s to the 2000s. Am J Prev Med. 2010;39(4):352-356.

24. Rabe KF, Hurd S, Anzueto A, et al; Global Initiative for Chronic Obstructive Lung Disease. Global strategy for the diagnosis, management, and prevention of chronic obstructive pulmonary disease: GOLD executive summary. Am J Respir Crit Care Med. 2007;176(6):532-555.

25. Celli BR, MacNee W; ATS/ERS Task Force. Standards for the diagnosis and treatment of patients with COPD: a summary of the ATS/ ERS position paper. Eur Respir J. 2004;23(6):932-946.

26. Hogg JC, Chu F, Utokaparch S, et al. The nature of small-airway obstruction in chronic obstructive pulmonary disease. $N$ Engl J Med. 2004;350(26):2645-2653.

27. Hurst JR, Vestbo J, Anzueto A, et al; Evaluation of COPD Longitudinally to Identify Predictive Surrogate Endpoints (ECLIPSE) Investigators. Susceptibility to exacerbation in chronic obstructive pulmonary disease. N Engl J Med. 2010;363(12):1128-1138.

28. Marquis K, Debigaré R, Lacasse Y, et al. Midthigh muscle crosssectional area is a better predictor of mortality than body mass index in patients with chronic obstructive pulmonary disease. Am J Respir Crit Care Med. 2002;166(6):809-813

29. Moed HF. New developments in the use of citation analysis in research evaluation. Arch Immunol Ther Exp (Warsz). 2009;57(1):13-18.
30. Nielsen FE. [Publication outcome of research funding by the Danish Heart Foundation 1988-1990]. Ugeskr Laeger. 1998;160(32):4644-4648. Danish.

31. Marx W, Schier H, Wanitschek M. Citation analysis using online databases: feasibilities and shortcomings. Scientometrics. 2001; 52(1):59-82.

32. Garfield E. 100 citation classics from the Journal of the American Medical Association. JAMA. 1987;257(1):52-59.

33. Hall GM. BJA citation classics 1945-1992. Br J Anaesth. 1998;80(1): 4-6.

34. Seglen PO. Why the impact factor of journals should not be used for evaluating research. BMJ. 1997;314(7079):498-502.

35. Celli BR, Cote CG, Marin JM, et al. The body-mass index, airflow obstruction, dyspnea, and exercise capacity index in chronic obstructive pulmonary disease. $N$ Engl J Med. 2004;350(10):1005-1012.

36. Calverley PMA, Anderson JA, Celli B, et al; TORCH investigators. Salmeterol and fluticasone propionate and survival in chronic obstructive pulmonary disease. $N$ Engl J Med. 2007;356(8): 775-789.

37. Anthonisen NR, Manfreda J, Warren CP, Hershfield ES, Harding GK, Nelson NA. Antibiotic therapy in exacerbations of chronic obstructive pulmonary disease. Ann Intern Med. 1987;106(2):196-204.

38. Siafakas NM, Vermeire P, Pride NB, et al. Optimal assessment and management of chronic obstructive pulmonary disease (COPD). Eur Respir J. 1995;8(8):1398-1420.

39. Brochard L, Mancebo J, Wysocki M, et al. Noninvasive ventilation for acute exacerbations of chronic obstructive pulmonary disease. $N$ Engl J Med. 1995;333(13):817-822.

40. Keatings VM, Collins PD, Scott DM, Barnes PJ. Differences in interleukin- 8 and tumor necrosis factor-alpha in induced sputum from patients with chronic obstructive pulmonary disease or asthma. Am J Respir Crit Care Med. 1996;153(2):530-534.

41. Seemungal TA, Donaldson GC, Paul EA, Bestall JC, Jeffries DJ, Wedzicha JA. Effect of exacerbation on quality of life in patients with chronic obstructive pulmonary disease. Am J Respir Crit Care Med. 1998;157(5 Pt 1):1418-1422.

42. Burge PS, Calverley PM, Jones PW, Spencer S, Anderson JA, Maslen TK. Randomised, double blind, placebo controlled study of fluticasone propionate in patients with moderate to severe chronic obstructive pulmonary disease: the ISOLDE trial. BMJ. 2000;320(7245):1297-1303.

43. Tashkin DP, Celli B, Senn S, et al; UPLIFT Study Investigators. A 4-year trial of tiotropium in chronic obstructive pulmonary disease. N Engl J Med. 2008;359(15):1543-1554.

44. Donaldson GC, Seemungal TA, Bhowmik A, Wedzicha JA. Relationship between exacerbation frequency and lung function decline in chronic obstructive pulmonary disease. Thorax. 2002;57(10):847-852.

45. Barnes PJ. Chronic obstructive pulmonary disease. N Engl J Med. 2000; 343(4):269-280.

46. Gan WQ, Man SF, Senthilselvan A, Sin DD. Association between chronic obstructive pulmonary disease and systemic inflammation: a systematic review and a meta-analysis. Thorax. 2004;59(7):574-580.

47. Barnes PJ, Shapiro SD, Pauwels RA. Chronic obstructive pulmonary disease: molecular and cellular mechanisms. Eur Respir J. 2003;22(4): 672-688.

48. Cooper JD, Trulock EP, Triantafillou AN, et al. Bilateral pneumectomy (volume reduction) for chronic obstructive pulmonary disease. J Thorac Cardiovasc Surg. 1995;109(1):106-116; discussion 116-119.

49. Calverley P, Pauwels R, Vestbo J, et al; TRial of Inhaled STeroids ANd long-acting beta 2 agonists study group. Combined salmeterol and fluticasone in the treatment of chronic obstructive pulmonary disease: a randomised controlled trial. Lancet. 2003;361(9356):449-456.

50. Bestall JC, Paul EA, Garrod R, Garnham R, Jones PW, Wedzicha JA. Usefulness of the Medical Research Council (MRC) dyspnoea scale as a measure of disability in patients with chronic obstructive pulmonary disease. Thorax. 1999;54(7):581-586. 
51. Buist AS, McBurnie MA, Vollmer WM, et al; BOLD Collaborative Research Group. International variation in the prevalence of COPD (the BOLD Study): a population-based prevalence study. Lancet. 2007;370(9589):741-750.

52. Pauwels RA, Löfdahl CG, Laitinen LA, et al. Long-term treatment with inhaled budesonide in persons with mild chronic obstructive pulmonary disease who continue smoking. European Respiratory Society Study on Chronic Obstructive Pulmonary Disease. N Engl J Med. 1999;340(25):1948-1953.

53. Schols AM, Slangen J, Volovics L, Wouters EF. Weight loss is a reversible factor in the prognosis of chronic obstructive pulmonary disease. Am J Respir Crit Care Med. 1998;157(6 Pt 1):1791-1797.

54. Ries AL, Kaplan RM, Limberg TM, Prewitt LM. Effects of pulmonary rehabilitation on physiologic and psychosocial outcomes in patients with chronic obstructive pulmonary disease. Ann Intern Med. 1995;122(11):823-832.

55. Repine JE, Bast A, Lankhorst I; The Oxidative Stress Study Group. Oxidative stress in chronic obstructive pulmonary disease. Am J Respir Crit Care Med. 1997;156(2):341-357.

56. Casaburi R, Mahler DA, Jones PW, et al. A long-term evaluation of once-daily inhaled tiotropium in chronic obstructive pulmonary disease. Eur Respir J. 2002;19(2):217-224.

57. Mannino DM, Buist AS. Global burden of COPD: risk factors, prevalence, and future trends. Lancet. 2007;370(9589):765-773.

58. Rahman I, Morrison D, Donaldson K, MacNee W. Systemic oxidative stress in asthma, COPD, and smokers. Am J Respir Crit Care Med. 1996;154(4 Pt 1):1055-1060.

59. Sethi S, Evans N, Grant BJ, Murphy TF. New strains of bacteria and exacerbations of chronic obstructive pulmonary disease. $N$ Engl J Med. 2002;347(7):465-471.

60. Plant PK, Owen JL, Elliott MW. Early use of non-invasive ventilation for acute exacerbations of chronic obstructive pulmonary disease on general respiratory wards: a multicentre randomised controlled trial. Lancet. 2000;355(9219):1931-1935.

61. Sin DD, Man SF. Why are patients with chronic obstructive pulmonary disease at increased risk of cardiovascular diseases? The potential role of systemic inflammation in chronic obstructive pulmonary disease. Circulation. 2003;107(11):1514-1519.

62. Seemungal TAR, Donaldson GC, Bhowmik A, Jeffries DJ, Wedzicha JA. Time course and recovery of exacerbations in patients with chronic obstructive pulmonary disease. Am J Respir Crit Care Med. 2000;161(5):1608-1613.

63. Altose MD, Redline S, Deitz CD, et al. Effect of inhaled triamcinolone on the decline in pulmonary function in chronic obstructive pulmonary disease. N Engl J Med. 2000;343(26):1902-1909.

64. Vestbo J, Sørensen T, Lange P, Brix A, Torre P, Viskum K. Longterm effect of inhaled budesonide in mild and moderate chronic obstructive pulmonary disease: a randomised controlled trial. Lancet. 1999;353(9167):1819-1823.

65. Vincken W, van Noord JA, Greefhorst AP, et al; Dutch/Belgian Tiotropium Study Group. Improved health outcomes in patients with COPD during 1 yr's treatment with tiotropium. Eur Respir J. 2002;19(2):209-216.

66. Gosselink R, Troosters T, Decramer M. Peripheral muscle weakness contributes to exercise limitation in COPD. Am J Respir Crit Care Med. 1996;153(3):976-980.

67. Seemungal T, Harper-Owen R, Bhowmik A, et al. Respiratory viruses, symptoms, and inflammatory markers in acute exacerbations and stable chronic obstructive pulmonary disease. Am J Respir Crit Care Med. 2001;164(9):1618-1623.

68. Ito K, Ito M, Elliott WM, et al. Decreased histone deacetylase activity in chronic obstructive pulmonary disease. NEngl J Med. 2005;352(19): 1967-1976.

69. Szafranski W, Cukier A, Ramirez A, et al. Efficacy and safety of budesonide/formoterol in the management of chronic obstructive pulmonary disease. Eur Respir J. 2003;21(1):74-81.

70. Saetta M, Di Stefano A, Turato G, et al. CD8+ T-lymphocytes in peripheral airways of smokers with chronic obstructive pulmonary disease. Am J Respir Crit Care Med. 1998;157(3 Pt 1):822-826.
71. Anthonisen NR, Wright EC, Hodgkin JE. Prognosis in chronic obstructive pulmonary-disease. Am Rev Respir Dis. 1986;133(1):14-20.

72. Hogg JC. Pathophysiology of airflow limitation in chronic obstructive pulmonary disease. Lancet. 2004;364(9435):709-721.

73. Landbo C, Prescott E, Lange P, Vestbo J, Almdal TP. Prognostic value of nutritional status in chronic obstructive pulmonary disease. $\mathrm{Am} J$ Respir Crit Care Med. 1999;160(6):1856-1861.

74. Soler-Cataluña JJ, Martinez-García MA, Román Sanchez PR, Salcedo E, Navarro M, Ochando R. Severe acute exacerbations and mortality in patients with chronic obstructive pulmonary disease. Thorax. 2005;60(11):925-931.

75. Kuwano K, Bosken CH, Paré PD, Bai TR, Wiggs BR, Hogg JC. Small airways dimensions in asthma and in chronic obstructive pulmonary disease. Am Rev Respir Dis. 1993;148(5):1220-1225.

76. Lacasse Y, Wong E, Guyatt GH, King D, Cook DJ, Goldstein RS. Metaanalysis of respiratory rehabilitation in chronic obstructive pulmonary disease. Lancet. 1996;348(9035):1115-1119.

77. Saint S, Bent S, Vittinghoff E, Grady D. Antibiotics in chronic obstructive pulmonary disease exacerbations. A meta-analysis. JAMA. 1995;273(12):957-960.

78. Barnes PJ. Immunology of asthma and chronic obstructive pulmonary disease. Nat Rev Immunol. 2008;8(3):183-192.

79. Niewoehner DE, Erbland ML, Deupree RH, et al. Effect of systemic glucocorticoids on exacerbations of chronic obstructive pulmonary disease. Department of Veterans Affairs Cooperative Study Group. $N$ Engl J Med. 1999;340(25):1941-1947.

80. Bernard S, LeBlanc P, Whittom F, et al. Peripheral muscle weakness in patients with chronic obstructive pulmonary-disease. Am J Respir Crit Care Med. 1998;158(2):629-634.

81. Bourbeau J, Julien M, Maltais F, et al; Chronic Obstructive Pulmonary Disease axis of the Respiratory Network Fonds de la Recherche en Santé du Québec. Reduction of hospital utilization in patients with chronic obstructive pulmonary disease: a disease-specific self-management intervention. Arch Intern Med. 2003;163(5):585-591.

82. O'Donnell DE, Flüge T, Gerken F, et al. Effects of tiotropium on lung hyperinflation, dyspnoea and exercise tolerance in COPD. Eur Respir J. 2004;23(6):832-840

83. Pitta F, Troosters T, Spruit MA, Probst VS, Decramer M, Gosselink R. Characteristics of physical activities in daily life in chronic obstructive pulmonary disease. Am J Respir Crit Care Med. 2005;171(9): 972-977.

84. Keatings VM, Jatakanon A, Worsdell YM, Barnes PJ. Effects of inhaled and oral glucocorticoids on inflammatory indices in asthma and COPD. Am J Respir Crit Care Med. 1997;155(2):542-548.

85. O'Donnell DE, Revill SM, Webb KA. Dynamic hyperinflation and exercise intolerance in chronic obstructive pulmonary disease. Am J Respir Crit Care Med. 2001;164(5):770-777.

86. Wiggs BR, Bosken C, Paré PD, James A, Hogg JC. A model of airway narrowing in asthma and in chronic obstructive pulmonary disease. $\mathrm{Am}$ Rev Respir Dis. 1992;145(6):1251-1258.

87. Pauwels RA, Rabe KF. Burden and clinical features of chronic obstructive pulmonary disease (COPD). Lancet. 2004;364(9434):613-620.

88. Halbert RJ, Natoli JL, Gano A, Badamgarav E, Buist AS, Mannino DM. Global burden of COPD: systematic review and meta-analysis. Eur Respir J. 2006;28(3):523-532.

89. Murphy TF, Sethi S. Bacterial infection in chronic obstructive pulmonary-disease. Am Rev Respir Dis. 1992;146(4):1067-1083.

90. McSweeny AJ, Grant I, Heaton RK, Adams KM, Timms RM. Life quality of patients with chronic obstructive pulmonary-disease. Arch Intern Med. 1982;142(3):473-478.

91. Schols AM, Soeters PB, Dingemans AM, Mostert R, Frantzen PJ, Wouters EF. Prevalence and characteristics of nutritional depletion in patients with stable COPD eligible for pulmonary rehabilitation. Am Rev Respir Dis. 1993;147(5):1151-1156.

92. Calverley PM, Boonsawat W, Cseke Z, Zhong N, Peterson S, Olsson H. Maintenance therapy with budesonide and formoterol in chronic obstructive pulmonary disease. Eur Respir J. 2003;22(6):912-919. 
93. Bhowmik A, Seemungal TA, Sapsford RJ, Wedzicha JA. Relation of sputum inflammatory markers to symptoms and lung function changes in COPD exacerbations. Thorax. 2000;55(2):114-120.

94. Lopez AD, Shibuya K, Rao C, et al. Chronic obstructive pulmonary disease: current burden and future projections. Eur Respir J. 2006;27(2):397-412.

95. Agusti AGN, Noguera A, Sauleda J, Sala E, Pons J, Busquets X. Systemic effects of chronic obstructive pulmonary disease. Eur Respir J. 2003;21(2):347-360.

96. Traver GA, Cline MG, Burrows B. Predictors of mortality in chronic obstructive pulmonary disease. A 15-year follow-up study. Am Rev Respir Dis. 1979;119(6):895-902.

97. Lambert RK, Wiggs BR, Kuwano K, Hogg JC, Paré PD. Functional significance of increased airway smooth muscle in asthma and COPD. J Appl Physiol (1985). 1993;74(6):2771-2781.

98. Wagner PD, Dantzker DR, Dueck R, et al. Ventilation-perfusion inequality in chronic obstructive pulmonary disease. J Clin Invest. 1977 ; 59(2):203-216

99. Barnes PJ, Celli BR. Systemic manifestations and comorbidities of COPD. Eur Respir J. 2009;33(5):1165-1185.

100. Jones PW, Bosh TK. Quality of life changes in COPD patients treated with salmeterol. Am J Respir Crit Care Med. 1997;155(4):1283-1289.

101. Montuschi P, Collins JV, Ciabattoni G, et al. Exhaled 8-isoprostane as an in vivo biomarker of lung oxidative stress in patients with COPD and healthy smokers. Am J Respir Crit Care Med. 2000;162(3 Pt 1):1175-1177.

102. Mahler DA, Donohue JF, Barbee RA, et al. Efficacy of salmeterol xinafoate in the treatment of COPD. Chest. 1999;115(4):957-965.

103. Nava S, Ambrosino N, Clini E, et al. Noninvasive mechanical ventilation in the weaning of patients with respiratory failure due to chronic obstructive pulmonary disease. A randomized, controlled trial. Ann Intern Med. 1998;128(9):721-728.

104. Cazzola M, MacNee W, Martinez FJ, et al; American Thoracic Society; European Respiratory Society Task Force on outcomes of COPD. Outcomes for COPD pharmacological trials: from lung function to biomarkers. Eur Respir J. 2008;31(2):416-469.

105. Monsó E, Ruiz J, Rosell A, et al. Bacterial infection in chronic obstructive pulmonary disease. A study of stable and exacerbated outpatients using the protected specimen brush. Am J Respir Crit Care Med. 1995;152(4 Pt 1):1316-1320.

106. Renzetti AD, McClement JH, Litt BD. The Veterans Administration cooperative study of pulmonary function. 3. Mortality in relation to respiratory function in chronic obstructive pulmonary disease. $\mathrm{Am} \mathrm{J}$ Med. 1966;41(1):115-129.

107. Maltais F, Simard AA, Simard C, Jobin J, Desgagnés P, LeBlanc P. Oxidative capacity of the skeletal muscle and lactic acid kinetics during exercise in normal subjects and in patients with COPD. Am J Respir Crit Care Med. 1996;153(1):288-293.

108. Wilson DO, Rogers RM, Wright EC, Anthonisen NR. Body weight in chronic obstructive pulmonary disease. The National Institutes of Health Intermittent Positive-Pressure Breathing Trial. Am Rev Respir Dis. 1989;139(6):1435-1438.

109. Seneff MG, Wagner DP, Wagner RP, Zimmerman JE, Knaus WA. Hospital and 1-year survival of patients admitted to intensive care units with acute exacerbation of chronic obstructive pulmonary disease. JAMA. 1995;274(23):1852-1857.

110. Scanlon PD, Connett JE, Waller LA, et al; Lung Health Study Research Group. Smoking cessation and lung function in mild-to-moderate chronic obstructive pulmonary disease. The Lung Health Study. Am J Respir Crit Care Med. 2000;161(2 Pt 1):381-390.

111. Paggiaro PL, Dahle R, Bakran I, Frith L, Hollingworth K, Efthimiou J. Multicentre randomised placebo-controlled trial of inhaled fluticasone propionate in patients with chronic obstructive pulmonary disease. International COPD Study Group. Lancet. 1998;351(9105):773-780.

112. Celli BR, Thomas NE, Anderson JA, et al. Effect of pharmacotherapy on rate of decline of lung function in chronic obstructive pulmonary disease: results from the TORCH study. Am J Respir Crit Care Med. 2008;178(4):332-338.
113. Vestbo J, Prescott E, Lange P. Association of chronic mucus hypersecretion with FEV1 decline and chronic obstructive pulmonary disease morbidity. Copenhagen City Heart Study Group. Am J Respir Crit Care Med. 1996;153(5):1530-1535.

114. Papi A, Bellettato CM, Braccioni F, et al. Infections and airway inflammation in chronic obstructive pulmonary disease severe exacerbations. Am J Respir Crit Care Med. 2006;173(10):1114-1121.

115. Saetta M, Turato G, Maestrelli P, Mapp CE, Fabbri LM. Cellular and structural bases of chronic obstructive pulmonary disease. Am J Respir Crit Care Med. 2001;163(6):1304-1309.

116. Di Francia M, Barbier D, Mege JL, Orehek J. Tumor necrosis factoralpha levels and weight loss in chronic obstructive pulmonary disease. Am J Respir Crit Care Med. 1994;150(5 Pt 1):1453-1455.

117. Schols AM, Buurman WA, Staal van den Brekel AJ, Dentener MA, Wouters EF. Evidence for a relation between metabolic derangements and increased levels of inflammatory mediators in a subgroup of patients with chronic obstructive pulmonary disease. Thorax. 1996;51(8):819-824.

118. Rahman I, Adcock IM. Oxidative stress and redox regulation of lung inflammation in COPD. Eur Respir J. 2006;28(1):219-242.

119. Sethi S, Murphy TF. Bacterial infection in chronic obstructive pulmonary disease in 2000: a state-of-the-art review. Clin Microbiol Rev. 2001;14(2):336-363.

120. Wedzicha JA, Calverley PM, Seemungal TA, Hagan G, Ansari Z, Stockley RA; INSPIRE Investigators. The prevention of chronic obstructive pulmonary disease exacerbations by salmeterol/fluticasone propionate or tiotropium bromide. Am J Respir Crit Care Med. 2008; 177(1):19-26.

121. Dekhuijzen PN, Aben KK, Dekker I, et al. Increased exhalation of hydrogen peroxide in patients with stable and unstable chronic obstructive pulmonary disease. Am J Respir Crit Care Med. 1996;154(3 Pt 1):813-816.

122. Donohue JF, van Noord JA, Bateman ED, et al. A 6-month, placebocontrolled study comparing lung function and health status changes in COPD patients treated with tiotropium or salmeterol. Chest. 2002;122(1):47-55.

123. Nishimura K, Izumi T, Tsukino M, Oga T. Dyspnea is a better predictor of 5-year survival than airway obstruction in patients with COPD. Chest. 2002;121(5):1434-1440.

124. Menezes AM, Perez-Padilla R, Jardim JR, et al; PLATINO Team. Chronic obstructive pulmonary disease in five Latin American cities (the PLATINO study): a prevalence study. Lancet. 2005; 366(9500):1875-1881

125. Patel IS, Seemungal TA, Wilks M, Lloyd-Owen SJ, Donaldson GC, Wedzicha JA. Relationship between bacterial colonisation and the frequency, character, and severity of COPD exacerbations. Thorax. 2002;57(9):759-764.

126. O’Donnell DE, Lam M, Webb KA. Measurement of symptoms, lung hyperinflation, and endurance during exercise in chronic obstructive pulmonary disease. Am J Respir Crit Care Med. 1998;158(5 Pt 1): $1557-1565$.

127. Aaron SD, Vandemheen KL, Fergusson D, et al; Canadian Thoracic Society/Canadian Respiratory Clinical Research Consortium. Tiotropium in combination with placebo, salmeterol, or fluticasonesalmeterol for treatment of chronic obstructive pulmonary disease: a randomized trial. Ann Intern Med. 2007;146(8):545-555.

128. Weitzenblum E, Hirth C, Ducolone A, Mirhom R, Rasaholinjanahary J, Ehrhart M. Prognostic value of pulmonary artery pressure in chronic obstructive pulmonary disease. Thorax. 1981;36(10):752-758.

129. Kanner RE, Anthonisen NR, Connett JE; Lung Health Study Research Group. Lower respiratory illnesses promote FEV(1) decline in current smokers but not ex-smokers with mild chronic obstructive pulmonary disease: results from the lung health study. Am J Respir Crit Care Med. 2001;164(3):358-364. 


\section{Publish your work in this journal}

The International Journal of COPD is an international, peer-reviewed journal of therapeutics and pharmacology focusing on concise rapid reporting of clinical studies and reviews in COPD. Special focus is given to the pathophysiological processes underlying the disease, intervention programs, patient focused education, and self management protocols.

This journal is indexed on PubMed Central, MedLine and CAS. The manuscript management system is completely online and includes a very quick and fair peer-review system, which is all easy to use. Visit http://www.dovepress.com/testimonials.php to read real quotes from published authors.

Submit your manuscript here: http://www.dovepress.com/international-journal-of-chronic-obstructive-pulmonary-disease-journal 